\title{
Analysis of the strategies for the commercialization of electric energy of generating agents in the short term environment
}

\section{Análise das estratégias de comercialização de energia elétrica de agentes geradores no ambiente de curto prazo}

\author{
Anny Key de Souza Mendonça '(iD), Silvio Aparecido da Silva ' (D), Luísa Zeredo Pereira' (iD \\ Antonio Cezar Bornia 1(D), Dalton Francisco de Andrade I(ID) \\ ' Federal University of Santa Catarina, Florianópolis
}

\begin{abstract}
The development of the electric energy market has gained visibility due to the recent transformations in energy policies in Brazil and worldwide. For many years, investments were not made in the Brazilian electricity sector, causing a delay in the energy matrix. With this, the government implemented measures for structural and institutional reforms in the electricity sector with the objective of guaranteeing the expansion of the generating park, attracting private investment, and promoting market competition. The restructuring of the electricity sector led to the emergence of new ways to negotiate energy, new structures and entities, with the objective of increasing transparency, competitiveness and efficiency among market agents. In the new model of the Brazilian Electricity Sector (SEB), energy trading is carried out through two contracting environments, the Regulated Contracting Environment (ACR) and the Free Contracting Environment ( $\mathrm{ACL}$ ). This research analyzes the electric energy commercialization strategies through generation agents acting and competing in the shortterm energy market, through the use of competitiveness graphs.
\end{abstract}

Keywords: Electricity Trading; Free energy Market; Trading strategies 


\section{RESUMO}

O desenvolvimento do mercado de energia elétrica ganhou visibilidade em virtude das recentes transformações nas políticas energéticas no Brasil e no mundo. Durante muito anos, investimentos não foram realizados no setor elétrico brasileiro, ocasionando um atraso na matriz energética. Com isso, o governo implementou medidas para reformas estruturais e institucionais no setor elétrico com objetivo de garantir a expansão do parque gerador, atrair investimentos privados e promover à concorrência do mercado. A reestruturação do setor elétrico levou ao aparecimento de novas formas de negociar energia, novas estruturas e entidades, com o objetivo de aumentar a transparência, a competitividade e a eficiência entre os agentes de mercado. No novo modelo do Setor Elétrico Brasileiro (SEB), a comercialização de energia é efetivada através de dois ambientes de contratação, o Ambiente de Contratação Regulado (ACR) e o Ambiente de Contratação Livre $(\mathrm{ACL})$. Esta pesquisa analisa as estratégias de comercialização de energia elétrica por meio de agentes de geração atuando e competindo no mercado de energia de curto prazo, por meio da utilização de gráficos de competitividade.

Palavras-chave: Comercialização de Energia Elétrica; Mercado livre de energia; Estratégias de comercialização

\section{INTRODUCTION}

The Brazilian Electric System (SEB) has a large number of power plants, thousands of kilometers of transmission lines and a large number of substations and control centers. The high complexity of managing all the equipment and the costs involved have encouraged the government, research groups, universities and companies to seek safe and efficient tools and techniques to operate and expand the national electrical system (NOGUEIRA and BERTUSSI, 2019).

In the 1990s, the government implemented measures for structural and institutional reforms in the electricity sector with the objective of guaranteeing the expansion of the generation park, and attracting private investments, since the government was showing signs of stagnation with the reduction in investments in the expansion of the system. These reforms were marked with the enactment of Law n॰ 8.631/93, which provided for the tariff structure for the public electric power service, extinguishing the guaranteed remuneration 
regime, and creating supply contracts between generators and distributors, aiming to reduce their financial difficulties (BRASIL, 1993).

Other important milestones can be highlighted for this reform, such as in 1995 the enactment of Law n॰9.074 that stimulated the participation of private initiative in the electric power generation sector, creating the independent power producer (PIE), being autonomous to act in the market and free to make their own decisions, assuming the results from such decisions (BRASIL, 1995; HUNT and SHUTTLEWORTH, 1996). This law initiated the competition in the commercialization of electricity with the introduction of the Free and Special Consumer, and in 1996 with the implementation of the Restructuring Project of the Brazilian Electric System (RE-SEB), which enabled the deverticalization of the sector (NOGUEIRA and BERTUSSI, 2019).

With the energy crisis that occurred in 2001, the government through Decree n॰5.163 created the new institutional model of the Brazilian Electric Sector (BRASIL, 2004). The new model created the Energy Research Company (EPE), with the function of developing studies and research for planning the expansion of the system. It also created the Energy Sector Monitoring Committee (CMSE), with the function of evaluating the security of electricity supply, and the Electric Energy Trading Chamber (CCEE), responsible for buying and selling electricity through two trading environments, called the Regulated Contracting Environment (ACR) and the Free Contracting Environment ACL (TOLMASQUIM, 2015; NOGUEIRA and BERTUSSI, 2019).

The new model for the electricity sector made possible the liberation and deregulation of the electricity market. The market restructuring process was intended to provide favorable conditions to stimulate competition and market efficiency for the benefit of society as a whole. In this scenario, the modification of paradigms inserted by the opening of markets evidenced the deverticalization of a state-controlled industry, providing the division of the areas of generation, transmission, distribution and commercialization of energy, and the creation of incentives for private agents to participate in the sector (HUNT and SHUTTLEWORTH, 1996; DA SILVA, 2001; RUDNICK and ZOLEZZI, 2001; HUNT, 2002; NERY, 2012; SIDDIQUI and GABRIEL, 2013). 
A competitive electricity market needs to establish a model with clear, stable rules and appropriate and effective regulation that provides a balanced relationship between all agents involved.

A market model is understood to mean methods and resources that enable negotiations to be done properly. More specifically, a market model consists of the means to organize the buying and selling of energy, through laws and regulations that define the rights and underpin the contracts, the market, and the regulatory standards (MCMILLAN, 2004).

A market model must be consistent with public policy in order to contribute to regulatory stability, which brings certainty to consumers, the energy market, and investors (KURI and LI, 2004). Therefore, it is important to observe the market and its behavior periodically, in order to provide continuous improvements so that it operates efficiently. An efficient model, based on a regulatory mechanism, helps to resolve the issues faced by electricity markets (STOFT, 2002). In this perspective, the electricity market is encouraged to develop and improve its market models to provide efficiency and economic growth through competition and sustainability, with guaranteed energy supply, with quality, reliability and fair cost to consumers (ZUCARATO, 2012).

This research analyzes the electric energy commercialization strategies in the period from 2012 to 2020 through generation agents acting and competing in the short-term energy market, through the use of competitiveness graphs.

\section{ELECTRICITY MARKET}

Several countries have changed the economics of their electricity markets from monopolies to oligopolies in an attempt to increase competition. The restructured electricity markets have enabled the deverticalization of the sector, creating competitiveness in the different activities of the value chain, providing several benefits for the sector. Some of these benefits were, the liberation and deregulation of the electricity sector in the late nineteenth century, marking the beginning of the introduction of competitiveness in some segments of 
the electricity sector, such as in the generation and commercialization of energy with the introduction of the Free and Special Consumer (RAMOS-REAL et al., 2009).

This restructuring introduced risks and uncertainties in a sector that was traditionally state-owned (HUANG, 2008; STREET et al., 2009). In the literature a number of contributions have been observed with respect to energy trading strategies in competitive environments. Some of these works focus on the Brazilian electricity market, which has specific trading rules. For example, (STREET et al., 2009) developed an optimization model to explore the optimal generation mix of biomass and small hydro plants. The proposed model composes an optimal portfolio of these two alternative generation sources, seeking to determine the best trading strategy to maximize the revenue of an energy trading company.

Teive et al. (2010) propose a mathematical model to support decision making to help the energy-trading agent to identify risk situations and opportunities to maximize the performance of its portfolio of energy contracts. The model takes into account energy reserve capacity constraints, using linear programming, as well as risk analysis using the VaR (Value at Risk) and CVaR (Conditional Value at Risk) methodologies.

De Amarante et al. (2018) developed a multi-stage optimal programming model addressing the supply strategy of a thermal generator considering price uncertainty.

Decker (2014) presented a decision support methodology for the trading of electricity from small hydropower plants. He used for this, a multi-stage stochastic optimization model with two levels. The first level is "strategic" and represents all annual trading decisions, while the second level is "operative" and the strategy of the first level is evaluated monthly according to market rules and opportunities.

Hesamzadeh and Biggar (2012) proposed a methodology to analyze extreme-Nash equilibria in a wholesale market.

Menniti et al. (2008) argue that the theory of non-cooperative games and the concept of Nash equilibrium, cannot be easily applied when a multiplayer game should be considered to simulate the operation of the electricity market. However, the authors suggest using evolutionary game theory with Nash equilibrium to simulate the electricity market in the presence of more than two generation agents. 
For Weber and Overbye (2002) Nash equilibrium can be a solution for bidding strategies in electricity markets. However, it is difficult to solve the market equilibrium problem because the characteristics of an electricity system, such as transmission constraints, make the market clearing mechanism difficult and make payoff functions non-differentiable. That is, the Nash equilibrium strategy may not exist, leaving only the mixed Nash equilibrium strategy.

As for Yang et al. (2011) the analysis of Nash equilibrium in electricity markets with imperfect competition is subject to two major challenges, the treatment of games with multiple players and the determination of the existence of multiple market equilibria. To solve these obstacles, the authors propose a solution method based on the payoff matrix approach and polynomial equations to calculate all market equilibria.

Belyaev (2010) states that the opening of the electricity market provided by the regulatory frameworks imposed by the government has caused an increase in energy transactions and related financial instruments to occur, corroborating the further development of the market.

The restructuring of the electricity system provided a secure, transparent, dynamic and reliable environment for the commercialization of energy. Energy may now be contracted according to $A C R$ or $A C L$ rules. Table 1 shows the main changes that occurred with the restructuring of the market.

Table 1 - Development of the electricity market in Brazil

\begin{tabular}{|c|c|c|c|}
\hline SEB until 1995 & \multicolumn{2}{|c|}{$\begin{array}{c}\text { Free market from } \\
1995-2003\end{array}$} & $\begin{array}{c}\text { New SEB model } \\
\text { as of } 2004\end{array}$ \\
\hline $\begin{array}{l}\text { Participation of } \\
\text { State Companies }\end{array}$ & $\begin{array}{l}\text { Opening of the marl } \\
\text { the beginning } \\
\text { privatization of com }\end{array}$ & $\begin{array}{r}\text { and } \\
\text { of } \\
\text { nies }\end{array}$ & $\begin{array}{l}\text { Participation of State and } \\
\text { Private Companies }\end{array}$ \\
\hline Monopoly & $\begin{array}{l}\text { Competition in } \\
\text { generation } \\
\text { commercialization } \\
\text { energy }\end{array}$ & $\begin{array}{l}\text { the } \\
\text { and } \\
\text { of }\end{array}$ & $\begin{array}{l}\text { Competition in the } \\
\text { generation and } \\
\text { commercialization of } \\
\text { energy }\end{array}$ \\
\hline
\end{tabular}




\begin{tabular}{|c|c|c|}
\hline $\begin{array}{l}\text { Captive } \\
\text { Consumers }\end{array}$ & Free and Captive Consumer & $\begin{array}{l}\text { Free and } \\
\text { Consumer }\end{array}$ \\
\hline Verticalized Sector & $\begin{array}{l}\text { The beginning of the } \\
\text { sector's deverticalization } \\
\text { with the division of the } \\
\text { generation, transmission, } \\
\text { distribution and } \\
\text { commercialization sectors }\end{array}$ & $\begin{array}{l}\text { Deverticalization of the } \\
\text { sector, activities divided } \\
\text { into generation, } \\
\text { transmission, } \\
\text { distribution, } \\
\text { commercialization, } \\
\text { import and export }\end{array}$ \\
\hline Public Financing & Public and private funding & $\begin{array}{l}\text { Public and private } \\
\text { funding }\end{array}$ \\
\hline $\begin{array}{l}\text { Tariffs } \\
\text { regulated }\end{array}$ & $\begin{array}{l}\text { Regulated tariffs in } \\
\text { distribution } \\
\text { transmission, but freely } \\
\text { negotiated in generation } \\
\text { and commercialization }\end{array}$ & $\begin{array}{l}A C L \text { - freely negotiated } \\
\text { price for generation and } \\
\text { commercialization and } \\
A C R \text { - the price for } \\
\text { distribution and } \\
\text { transmission of energy is } \\
\text { negotiated in auctions } \\
\text { and bids for the lowest } \\
\text { price }\end{array}$ \\
\hline $\begin{array}{l}\text { Total market } \\
\text { contracting } \\
\text { without penalty }\end{array}$ & $\begin{array}{l}\text { Contracting for distributors } \\
\text { and free market } 85 \% \text { by } \\
2003 \text { and } 95 \% \text { by } 2004\end{array}$ & $\begin{array}{l}\text { Total contracting of the } \\
\text { energy produced in the } \\
\text { market plus the reserve } \\
\text { energy }\end{array}$ \\
\hline $\begin{array}{l}\text { Settlement of } \\
\text { differences } \\
\text { (surpluses and } \\
\text { deficits) divided } \\
\text { between buyers }\end{array}$ & $\begin{array}{l}\text { Settlement of differences } \\
\text { (surpluses and deficits) } \\
\text { carried out at MAE }\end{array}$ & $\begin{array}{l}\text { Settlement of differences } \\
\text { (surpluses and deficits) in } \\
\text { the Short-Term Market } \\
\text { made at the CCEE }\end{array}$ \\
\hline $\begin{array}{l}\text { Planning prepared } \\
\text { by the Electric } \\
\text { Systems Planning } \\
\text { Coordinating } \\
\text { Group (GCPS) }\end{array}$ & $\begin{array}{l}\text { Planning prepared by } \\
\text { Eletrobras and the Ministry } \\
\text { of Mines and Energy (MME) }\end{array}$ & $\begin{array}{l}\text { Planning elaborated by } \\
\text { the Energy Research } \\
\text { Company (EPE) }\end{array}$ \\
\hline
\end{tabular}

Source: Adapted from (CCEE, 2019).

Most research has been done for hydroelectric and thermal power systems, where generators generally use bid-based pricing strategies for each hour of the day. 


\section{METHODOLOGY}

This article analyzes the electric energy commercialization strategies in the period from 2012 to 2020 through active generation agents and competing in the short-term energy market, through the use of competitiveness graphs.

For this purpose, a time series of the PLD of the electricity market was manipulated available on the website of the Electric Energy Trading Chamber (CCEE) (CCEE, 2020a). The data refer to January 2012 to September 2020, totaling 210 observations for each submarket analyzed (Southeast / Midwest, South, Northeast and North).

For this, the igraph library was used together with the R programming language, in order to build a graph based on the mapping generated between selling companies and buying companies. Each stretch is added to the graph as a vertex, and edges are included from the list of connections between the participating companies. Using the methods offered by igraph itself, some of the inherent properties of the network as a directed graph were calculated.

A directed graph is a network in which each edge has a direction from one vertex to another, that is, each edge has the shape of an arrow (Newman, 2010), as can be seen in Figure 8. Mathematically, a directed graph $D$, consists of a collection of vertices $V$ and a collection of $\operatorname{arcs} A$, which we can represent by $D=(V, A)$ and each arc with specific adjacent vertices: tail and head (VAN STEEN, 2010).

The network are directed graphs represented by companies that buy and sell energy, the size of the vertex tells about the quantity bought and sold of energy in amounts of MWh.

\section{RESULTS AND DISCUSSION}

The commercialization of energy in the Brazilian Electric System (SEB) occurs between the agents participating in the Electrical Energy Commercialization Chamber (CCEE) by means of purchase and sale contracts. The CCEE accounts for the differences between the energy that was contracted and what was generated and consumed, this difference (the 
surplus) is valued through the price of settlement of differences (PLD) in the short-term market.

The commercialization of short-term energy in the free environment occurs with free negotiation among the agents involved. The purchase and sale of energy, the delivery period and the volume are freely negotiated between the agents and concluded through contracts registered with the CCEE.

The SEB's main source of generation is hydroelectric power plants. In times of little rain, these plants cannot be activated and thermal plants have to be put into operation. Because of this, the minimum price of energy observed in Figure 1 corresponds to the operational cost of a hydroelectric plant (UHE), while the maximum price corresponds to the operational cost of a thermoelectric plant (UTE) which are more expensive.

Figure 1 - Historical series of the difference settlement price (January 2012 to September 2020)

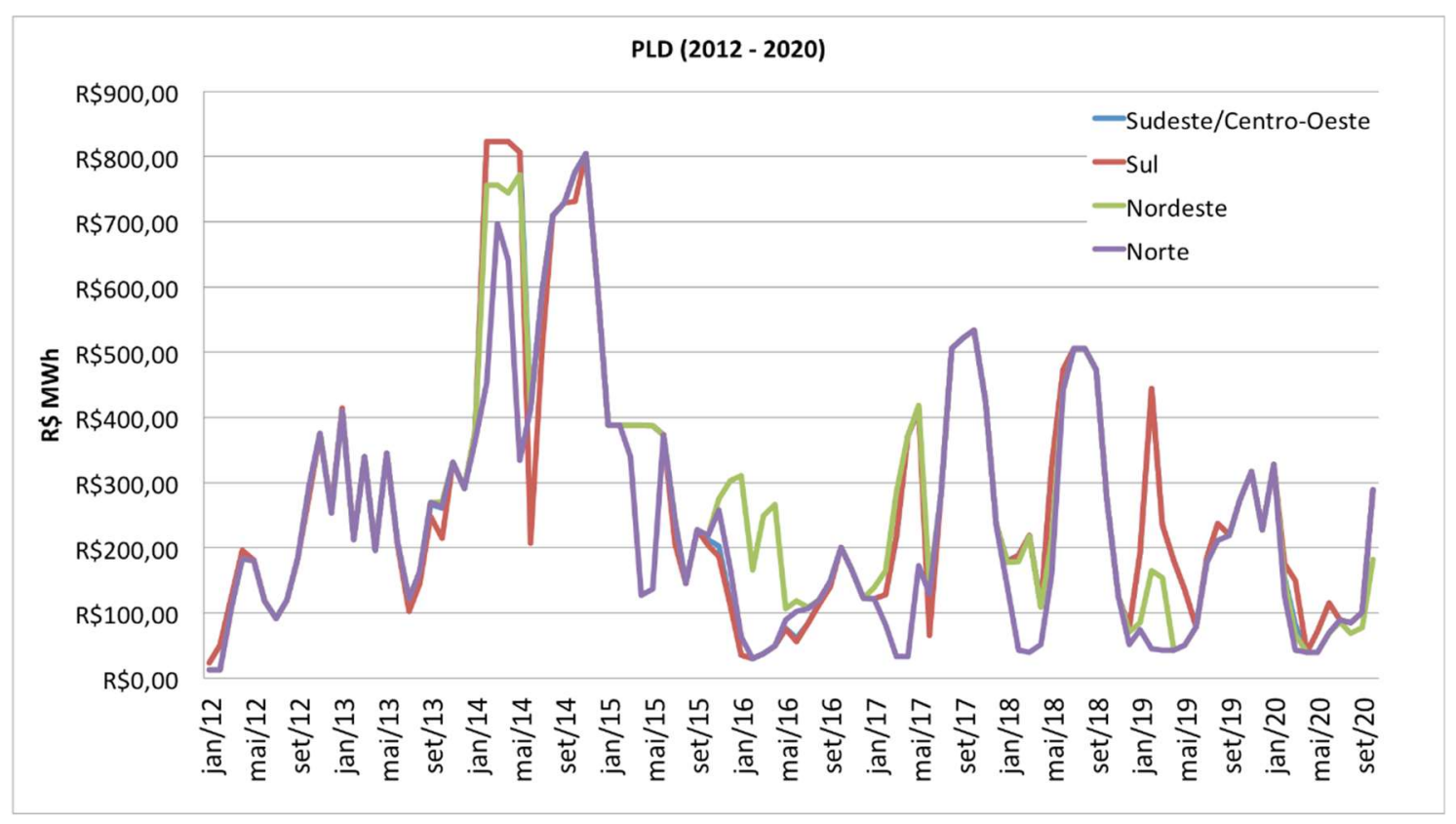

Source: Prepared by the authors with data from (CCEE, 2020a)

When analyzing the historical series of the PLD of the Southeast/Central-West, South, Northeast and North submarkets (Figure 1) between the period from January 2012 to September 2020, it is observed that the beginning of the decade was marked by a period of 
low price behavior followed by an increase in the following years. It is noted that prices are inconstant, with records of high prices, such as in the period between February and May 2014, when prices reached the mark of $822.83 \mathrm{R} \$ / \mathrm{MWh}$ and between August and November of the same year, when they reached prices between 709.53 to $804.54 \mathrm{R} \$ / \mathrm{MWh}$. In 2017, the PLD rose again, however, in this period it did not exceed the $533.82 \mathrm{R} \$ / \mathrm{MWh}$ mark.

The volatility of the PLD for example, in the months of January 2013 with the average energy price at $413.95 \mathrm{R} \$ / \mathrm{MWh}$, in February 2014 with $822.83 \mathrm{R} \$$ and September with 728.95 , and October 2017 with $533.82 \mathrm{R} \$ / \mathrm{MWh}$ show that energy production was very expensive at that time, this event being motivated by reasons such as, lack of rain and increase in energy consumption. This increase in price, influences the future curve of prices charged to the final consumer in the following year.

In 2020 approximately $1,084,730$ average MW of energy were transacted in the Brazilian market. Figure 2 shows the amount contracted in each type of contract.

Figure 2 - Contracts by type and amount in average MW

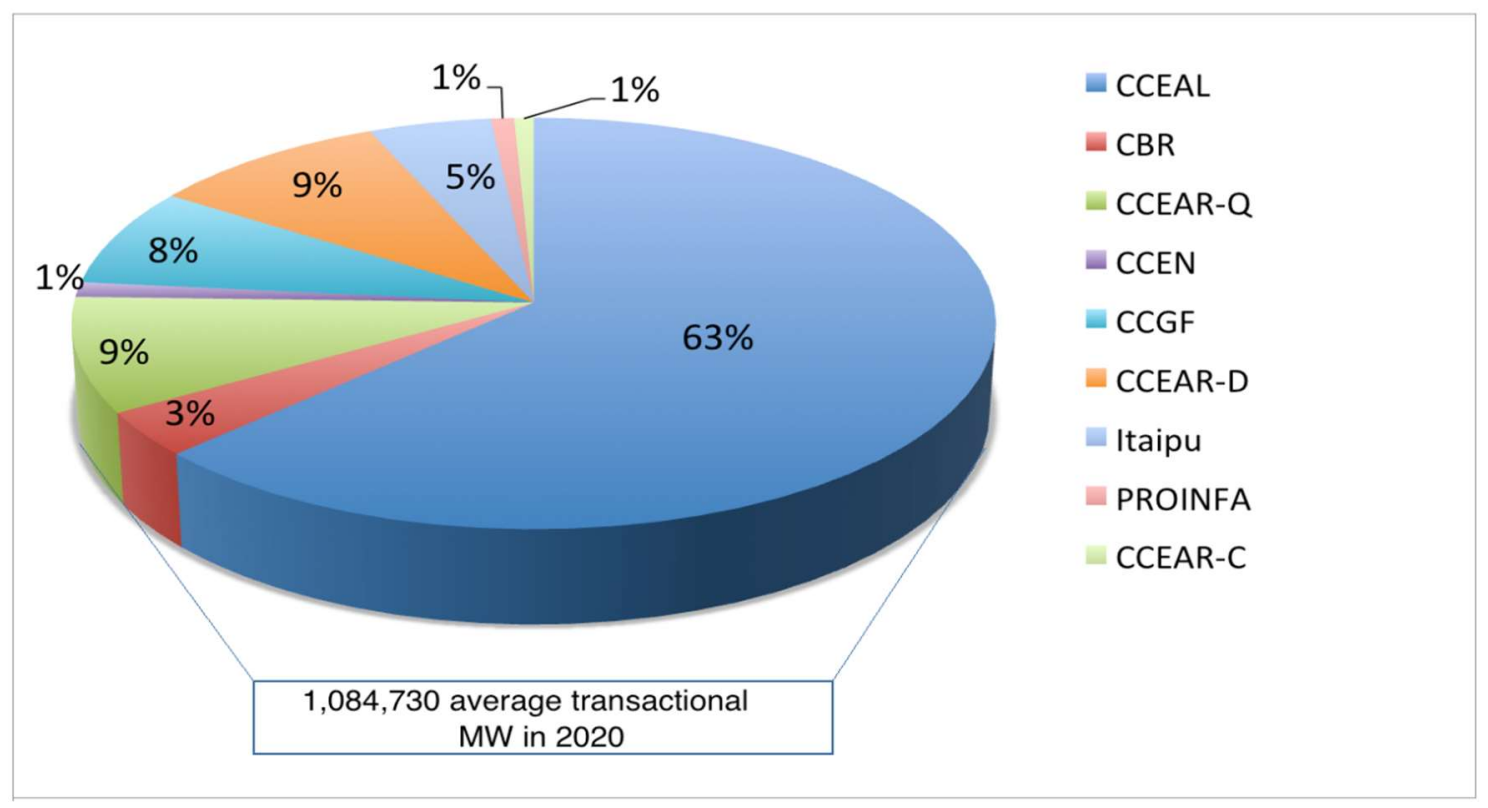

Source: Prepared by the authors with data from (CCEE, 2020b) 
Note in Figure 2 that $63 \%$ of the contracted energy was negotiated through electricity commercialization contracts in the free environment (CCEAL), followed by quantity contracts (CCEAR-Q) and availability contracts (CCEAR-D).

In the quantity contracts modality (CCEAR-Q), the seller is responsible for the delivery of a certain quantity of contracted energy and assumes the risks in case unfavorable hydrological conditions affect the energy supply. On the other hand, in the availability contracts modality (CCEAR-D), the seller commits to make available a specific volume of energy capacity and the costs resulting from hydrological risks are assumed by the buying agents.

The purchase contracts considered in the CCEAL were executed by Independent Producers, Auto-producers, Generators, Retailers, Free and Special Consumers and Distributors, representing a seasonalized volume of 110,293.68 average MW. Figure 3 presents the contracted amount in average MW and the duration of the contracts. Note that the contracted amount is higher in the 6 month to 1 -year period, followed by 1 -month contracts.

Figure 3 - Purchase contracts by duration and amount in CCEAL in average MW

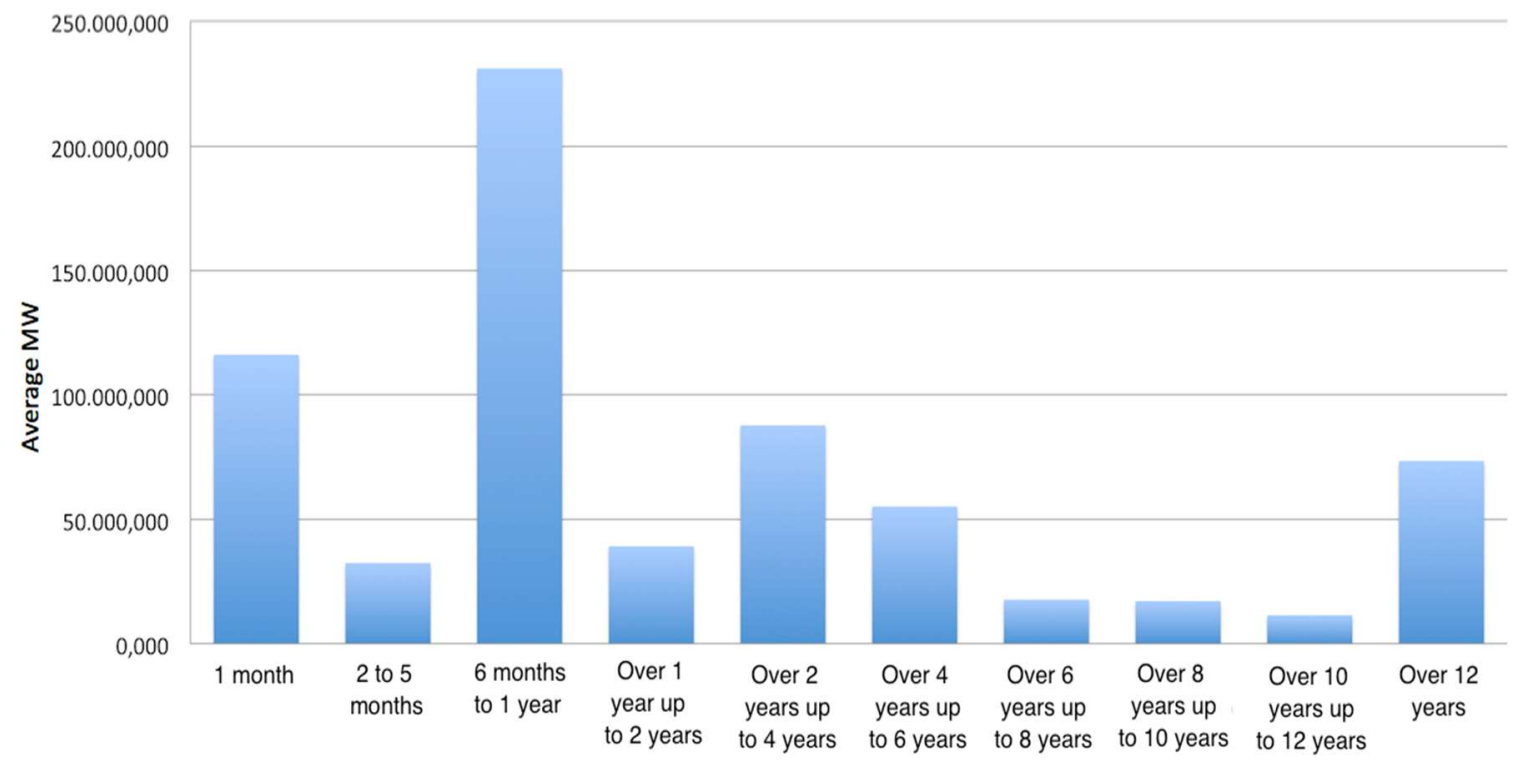

Source: Prepared by the authors with data from (Ccee, 2020b) 
According to Nogueira and Bertussi (2019), the free energy market is an essential tool to promote competition, efficiency and technological innovation in the national market.

Based on the data set of contracts for the sale of electricity on the free market, the method of competitiveness graphs was applied. The results show that the most competitive energy sources in the South submarket are those generated by the Hydroelectric, Wind and Small Hydroelectric sources as shown in Figure 4.

Figure 4: Graphs of the most competitive energy sources in the South Submarket

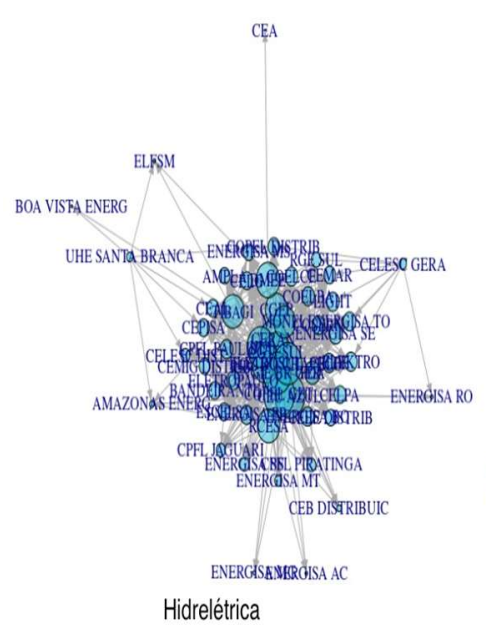

Hidrelétrica

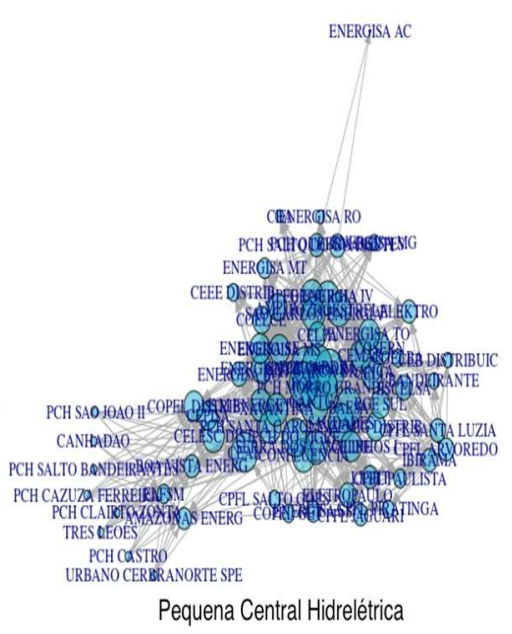

Pequena Central Hidrelétrica

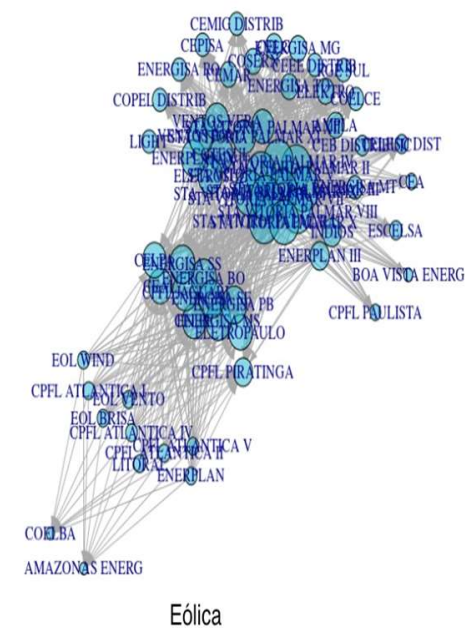

Eólica

Source: Prepared by the authors (2020)

The larger the circles in blue, the greater the number of contracts negotiated by the agents. The negotiation of the purchase and sale of wind power, involved 28 selling agents who negotiated 15,954,012.07 MWh in contracts. Of these 28 agents, the most competitive were in order, CPFL Atlanta V, CPFL Atlanta I, CPFL Atlanta II, CPFL Atlanta IV, CPFL Atlanta V and Eletrosul. The six largest selling agents, negotiated together 5,313,989.00 MWh in contracts in 2020.

The largest volumes negotiated come from the hydroelectric source with $89,663,498.76 \mathrm{MWh}$ negotiated for the South submarket. Among the agents, the six most competitive were the energy producers Engie Brasil GER, Foz do Chapecó Energia S.A, Copel GET, CGT Eletrosul, Geração Céu Azul S.A and DME ENERGETICA S.A. - DMEE. Engie Brasil is 
considered the largest energy producer in Brazil with 61 plants involving hydro, wind, solar and biomass with an installed capacity of 10,211 MW, being the most competitive among hydroelectric producers.

The twenty-seven agents generating small hydroelectric power plants, form a group that together negotiated 10,681,224.79 MWh, being considered the third most competitive source in the South of the country. The agents with the biggest contracts are the energy producers Serra dos Cavalinhos I Energética S.A, CPFL Energia Group (SALTO GOES), EM Energética, CPFL Energia Group (ARVOREDO), CEC CANOAS, EPP Energia - PCH Confluência.

The Biomass and Thermoelectric plants (Figure 5) have a reduced number of selling agents. The SEPE generation, UTE Madeiras and UTE Cambara plants are the only companies that sell energy through biomass. The SEPE generation plant is the company with the largest number of contracted businesses.

Figure 5: Graphs of growing energy sources in the South Submarket
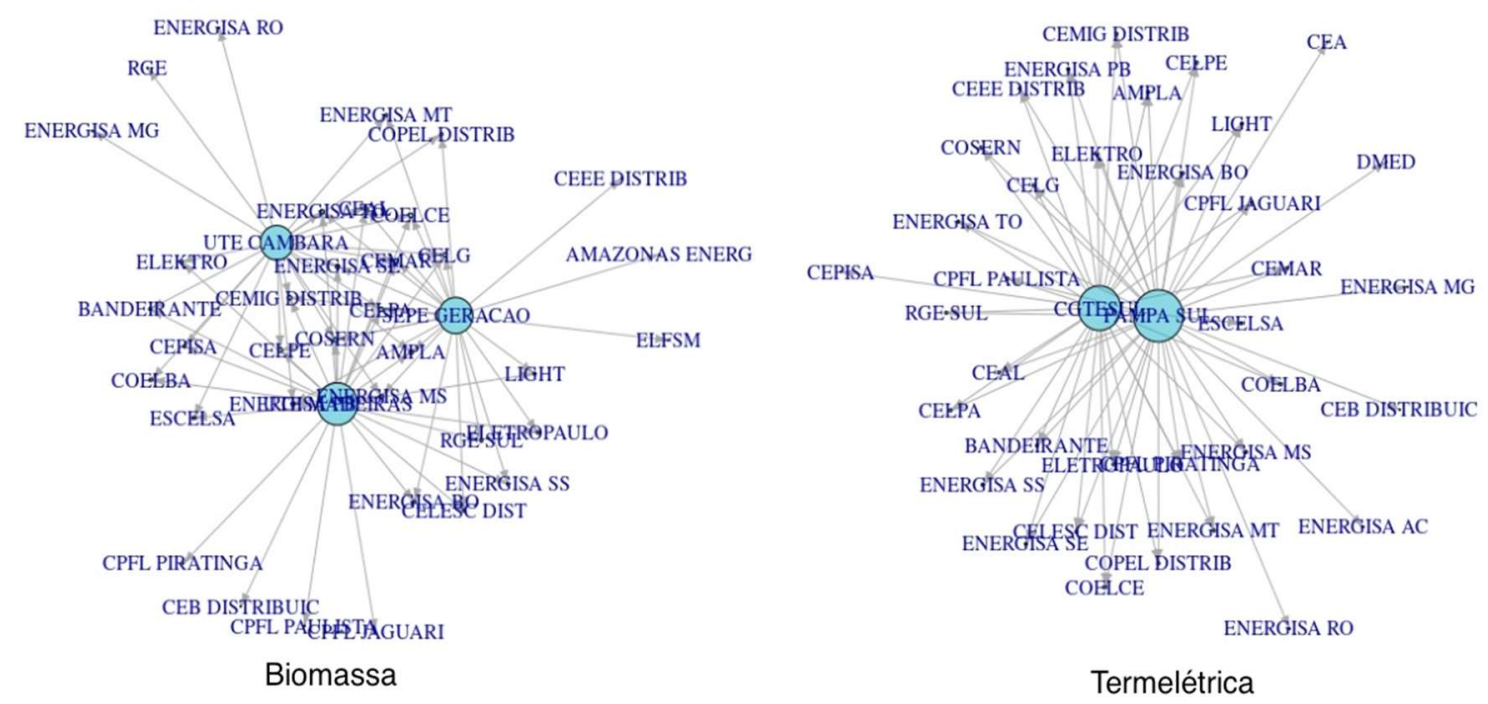

Source: Prepared by the authors (2020).

There are two thermoelectric plants, CGT Eletrosul (CGTESUL) and the Thermoelectric Plant Pampa Sul - ENGIE Brazil (PAMPA SUL). The energy from thermoelectric plants are negotiated when there is a reduction of water in the reservoirs of the hydroelectric plants, caused by the lack of rainfall, in these cases, the country resorts to the use of thermoelectric 
energy because it is very expensive. As 2020 is a year of drought almost all over the country, $30,606,192.11 \mathrm{MWh}$ of energy ends were negotiated to meet the energy consumption of the country.

In 2021, the hourly PLD model comes into force, giving more detailed and faster information to the sector's agents. The quantities sold are valued at different prices and terms, and can generate significant disbursements (DE AMARANTE et al., 2018). However, according to (OLIVEIRA, 2020), the hourly price will impact the valuation of the agent's exposure in the market, and as in any other speculative market, being exposed to price variation, will bring risks and opportunities, leaving the agent to take the decision to continue speculating and be subject to hourly price volatility, or to seek security in your contracts.

\section{CONCLUSION}

In this research the strategies for the commercialization of electric energy were analyzed by generation agents acting and competing in the short-term energy market, through the use of competitiveness graphs. The agents involved in the commercialization (buying and selling) of energy in the southern submarket were analyzed. It was seen that the agents buy according to the need of their energy demand. The contracts involve in their majority, purchases by duration and amounts in a period for six months to one year. Onemonth contracts were also seen; these contracts generally seek to supply extra consumption.

Among the largest generating agents, the most competitive were those that sell energy from hydroelectric, thermoelectric, wind and small hydroelectric plants. The most competitive were Engie Brasil GER, Usina Termelétrica Pampa Sul - ENGIE Brasil (PAMPA SUL) and the CPFL group (Atlanta V).

\section{ACLNOWLEDGMENTS}

The authors would like to thank the Coordination for the Improvement of Higher Education Personnel (CAPES) for funding this research project. 


\section{REFERENCES}

BELYAEV, L. S. Electricity market reforms: Economics and policy challenges. Springer Science \& Business Media, 2010. ISBN 1441956123.

BRASIL, C. C. Lei no 8.631 de 4 de março de 1993. Dispõe sobre a fixação dos níveis das tarifas para o serviço público de energia elétrica, extingue o regime de remuneração garantida e dá outras providênciasa saúde e dá outras providências. Diário Oficial da União, Brasília, DF: 1993. Disponível em: http://www.planalto.gov.br/ccivil_03/LEIS/L8631.htm. Acesso em: Maio de 2020., 1993.

BRASIL, C. C. Lei no 9.074 de 7 de julho de 1996. Estabelece normas para outorga e prorrogações das concessões e permissões de serviços públicos e dá outras providências. Diário Oficial da União, 1995.

BRASIL, C. C. Decreto n 5.163 de 2004. Julho 302004.

CCEE. Câmera de Comercialização de Energia Elétrica - Com quem se relaciona. Disponível em: http://www.ccee.org.br/portal/faces/pages_publico/onde-atuamos/ com_quem_se_relaciona?_adf.ctrlstate=vlbs7aekt_227\&_afrLoop $=900499606492978$ - !, Acessado em: Maio de 2020. 2019.

CCEE. Média mensal do Preço de Liquidação das Diferenças (PLD): Preços em formato XLS. Disponível em: https://www.ccee.org.br/portal/faces/pages_publico/oquefazemos/como_ccee_atua/precos/precos_medios?_afrLoop $=530316616216204 \&$ _adf.ctrlstate $=88 y 47$ ozez_93- $! \% 40 \% 40 \% 3 F \_a f r L o o p=530316616216204 \% 26 \_$adf.ctrl-state=88y47ozez_97, acesso em outubro de 2020. 2020a.

CCEE. InfoMercado dados de contratos. Disponível em: https://www.ccee.org.br/portal/faces/pages_publico/oquefazemos/download_contratos?_adf.ctrlstate $=z l w 1$ knycx_42\&_afrLoop=681560759195938-!, acessado em outubro de 2020., 2020b.

DA SILVA, E. L. Formação de preços em mercados de energia elétrica. Sagra Luzzatto, 2001. ISBN 8524106468.

DE AMARANTE, A. et al. Um Comparativo entre o Modelo Autorregressivo Vetorial e o Modelo Computacional Newave-Decomp na Gestão da Previsão do Preço Spot de Energia Elétrica no Brasil. Encontro de Gestão e Negócios (EGEN). 2018. ISSN 1751-8695.

DECKER, B. U. Um modelo de otimização estocástica para apoio à decisão na comercialização de energia elétrica de pequenas centrais hidrelétricas com técnicas de aversão ao risco. Dissertação (mestrado) - Universidade Federal de Santa Catarina, Centro Tecnológico, Programa de PósGraduação em Engenharia Elétrica, Florianópolis, 2014.

HESAMZADEH, M. R.; BIGGAR, D. R. Merger analysis in wholesale power markets using the equilibriaband methodology. IEEE Transactions on Power Systems, v. 28, n. 2, p. 819-827, 2012. ISSN 08858950. 
HUANG, X. Portfolio selection with a new definition of risk. European Journal of operational research, v. 186, n. 1, p. 351-357, 2008. ISSN 0377-2217.

HUNT, S. Making competition work in electricity. John Wiley \& Sons, 2002. ISBN 0471266027.

HUNT, S.; SHUTTLEWORTH, G. Competition and choice in electricity. John Wiley \& Sons Chichester, 1996.

KURI, B.; LI, F. Effective design for competitive electricity markets. 39th International Universities Power Engineering Conference, 2004. UPEC 2004., 2004, IEEE. p.1034-1038.

MCMILLAN, J. A reinvenção do bazar: uma história dos mercados. Zahar, 2004. ISBN 8571108218.

MENDONÇA, A. K. D. S. et al. Comparing patent and scientific literature in airborne wind energy. Sustainability, v. 9, n. 6, p. 915, 2017.

MENNITI, D.; PINNARELLI, A.; SORRENTINO, N. Simulation of producers behaviour in the electricity market by evolutionary games. Electric Power Systems Research, v. 78, n. 3, p. 475-483, 2008. ISSN 0378-7796.

MME. Modelo Institucional do Setor Elétrico. Disponível em: https://www.google.com/search?q=MME ++Modelo + +de+Comercializa\%C3\%A7\%C3 \%A3o+de+E nergia + El\%C3\%A9trica\&client $=$ safari\&rls $=$ en\&source $=$ Inms\&sa $=X \& v e d=0$ ahUKEwijosmF5b7iAhVz FLkGHQLmAbYQ_AUICSgA\&biw=765\&bih=852\&dpr=1, acesso em abril de 2019.: Ministério de Minas e Energia, Brasília., 2003.

NERY, E. Mercados e regulação de energia elétrica. Rio de Janeiro: Interciência, 2012.

NOGUEIRA, A. C. M. L.; BERTUSSI, G. L. O setor de energia elétrica brasileiro e a perspectiva de uma reforma setorial. Revista da Universidade Federal de Minas Gerais, v. 26, n. 1 e 2, p. 16-45, 2019. ISSN 2316-770X.

OLIVEIRA, C. R. D. Estudo do futuro preço horário de energia e seu efeito sobre os contratos de consumidores livres no setor elétrico brasileiro. 2020.

RAMOS-REAL, F. J. et al. The evolution and main determinants of productivity in Brazilian electricity distribution 1998-2005: An empirical analysis. Energy Economics, v. 31, n. 2, p. 298-305, 2009. ISSN 0140-9883.

RUDNICK, H.; ZOLEZZI, J. Electric sector deregulation and restructuring in Latin America: lessons to be learnt and possible ways forward. IEE Proceedings-Generation, Transmission and Distribution, $\mathrm{v}$. 148, n. 2, p. 180-184, 2001. ISSN 1359-7051.

SIDDIQUI, S.; GABRIEL, S. A. An SOS1-based approach for solving MPECs with a natural gas market application. Networks and Spatial Economics, v. 13, n. 2, p. 205-227, 2013. ISSN 1566-113X. 
STOFT, S. Power system economics. Journal of Energy Literature, v. 8, p. 94-99, 2002. ISSN 13593714.

STREET, A. et al. Risk constrained portfolio selection of renewable sources in hydrothermal electricity markets. IEEE Transactions on power systems, v. 24, n. 3, p. 1136-1144, 2009. ISSN 0885-8950.

TEIVE, R. et al. A decision support system for energy trading and portfolio optimization. 2010 7th International Conference on the European Energy Market, 2010, IEEE. p.1-6.

TOLMASQUIM, M. T. Novo modelo do setor elétrico brasileiro. Synergia Editora, $2^{\mathrm{a}}$ edição 2015.

TSENG, C.-L.; ZHU, W. Optimal self-scheduling and bidding strategy of a thermal unit subject to ramp constraints and price uncertainty. IET generation, transmission \& distribution, v. 4, n. 2, p. 125-137, 2010. ISSN 1751-8695.

VAN STEEN, M. (2010). Graph theory and complex networks. An introduction, 144.

WEBER, J. D.; OVERBYE, T. J. An individual welfare maximization algorithm for electricity markets. IEEE Transactions on Power Systems, v. 17, n. 3, p. 590-596, 2002. ISSN 0885-8950.

YANG, Y. et al. Computing all Nash equilibria of multiplayer games in electricity markets by solving polynomial equations. IEEE Transactions on power systems, v. 27, n. 1, p. 81-91, 2011. ISSN 08858950.

ZUCARATO, A. N. Mecanismos de capacidade em sistemas de energia elétrica com predominância de geração hidrelétrica. Tese (doutorado) - Universidade Federal de Santa Catarina, Centro Tecnológico, Programa de Pós-Graduação em Engenharia Elétrica, Florianópolis, 2009.

\section{AUTHORSHIP CONTRIBUTION}

\section{1 - Anny Key de Souza Mendonça}

Doctor in Production Engineering

E-mail: anny.mendonca@posgrad.ufsc.br | https://orcid.org/0000-0003-1640-8935

Contributed: Conceptualization, methodology, formal analysis, investigation, data curation, writing-original draft preparation.

\section{2 - Silvio Aparecido da Silva}

PhD student in Production Engineering

E- mail: silvio.silva@ifsc.edu.br

| https://orcid.org/0000-0003-0072-8651 
Contributed: Conceptualization, methodology, formal analysis, investigation, data curation, writing—original draft preparation.

\section{3 - Luísa Zeredo Pereira}

Undergraduate in Production and Systems Engineering Department

E-mail: Izpereira10@gmail.com | https://orcid.org/0000-0002-6190-7613

Contribuition: Writing.

\section{4 - Antonio Cezar Bornia}

Doctor in Production Engineering

E-mail: cezar.bornia@gmail.com | https://orcid.org/0000-0003-3468-7536

Contribuition: Validation, supervision, and visualization.

\section{5 - Dalton Francisco de Andrade}

$\mathrm{PhD}$ in Biostatistics

E- mail: dalton.andrade@ufsc.br | https://orcid.org/0000-0002-4403-980X

Contribuition: Validation, supervision, and visualization.

\section{HOW TO QUOTE THIS ARTICLE}

Mendonça, A. K. S. et. al.. Analysis of the strategies for the commercialization of electric energy of generating agents in the short term environment. Santa Maria, v.25, e14, 2021. Available from: https://doi.org/10.5902/2236117064441. Accessed: Month Abbreviated. Day, year. 